$<$ Editorial $>$

\title{
栄養障害と steatohepatitis：その根底にあるものは何か？
}

福井博

Kwashiorkor 症候群，吸収不良症候群，飢餓などの 高度の低栄養状態において肝機能障害が惹起されるこ とが以前から知られていだ．現在，欧米やわが国にお いてこれら栄養障害性肝障害が問題となることは稀で あるが，心身症として知られる神経性食思不振症 (Anorexia nervosa：AN) において相次いで著明な肝 障害が報告されている ${ }^{2-7)}$. 山口らは本号に低栄養のた めに重篤な nonalcoholic steatohepatitis (NASH) を きたした 1 症例を報告し, その根底に AN の存在を考 えている. また, 寺田ら ${ }^{81}$ は本誌 38 巻 10 号において $\mathrm{AN}$ のために肝不全死した 1 症例を報告しており，剖検結 果から肝組織像は同様にNASH であったと報告して いる.

NASH という呼称は, 1980年, Ludwig ら ${ }^{9)}$ が飲酒歴 がないにもかかわらず，アルコール性肝炎に類似する 組織像を呈した20症例を報告したことに端を発する。 本症では, 大滴性の脂肪肝に加えて, 炎症細胞浸潤を 伴う肝細胞壊死, マロリー小体, 肝細胞の ballooning, 中心静脈周囲性及び肝細胞周囲性の線維化や門脈域か ら小葉内に星芒状に伸びる線維化などが認められ $3^{8,9)}$. 一般の脂肪肝が予後良好であるのとは異なり, 時に急性肝不全に陥ったり ${ }^{10)}$, 肝硬変へ進展する ${ }^{11,12)}$ など, 重篤な経過をとり得ることが報告されている. 原因としては肥満とそれに対する空腸・回腸吻合術, 糖尿病, 薬物などが考えられている ${ }^{10,13)}$. この際, 脂肪 沈着と炎症との因果関係は明らかでなく ${ }^{12)}$, 疾患の重 症度は脂肪沈着の程度とは無関係で肝細胞障害の強さ に依存している ${ }^{1,11)}$.すなわち, 本症では脂肪沈着と肝 細胞壊死の発生機序は異なるようで, これらは互いに 独立して消長し得るものと考えられる ${ }^{11}$. 山口ら, 寺田 $ら^{8)}$ の症例は, 脂肪肝や NASH が過栄養のみならず, 正反対の低栄養条件下にも発生することを示唆してお り, 栄養障害において何故脂肪沈着や肝細胞壊死が起 こるのか, 原因が多様な steatohepatitis の本態は一体 何か, という非常に重要な問題を提起している.

\footnotetext{
*奈良県立医科大学第 3 内科
}

\section{1. 栄養障害と脂肪肝}

肝は脂質代謝の主要な場であり, 肝に過剩に沈着す る中性脂肪は脂肪酸から合成される. 肝における脂肪 酸は, 食事中の脂肪, 未梢脂肪組織からの動員, グル コースからの合成に由来する ${ }^{14)}$. 脂肪酸の一部はミト コンドリア内で酸化されるが，大部分は滑面小胞体で エステル化されて中性脂肪となり, ゴルジ装置でアポ 蛋白 B と結合して超低比重リポ蛋白 (VLDL) として 肝から分泌される ${ }^{(4)}$. 従って脂肪肝は糖質および脂質 の過剩摂取, 脂肪組織から肝への脂肪酸動員の増加, 肝における脂肪酸酸化の低下, 脂肪酸合成の亢進およ びVLDLの合成および分泌障害などのいずれか, また はこれらの組み合わせにより生ずるものである ${ }^{(4)}$. 飢 餓状態では, 血糖值が低下するため, 大量の遊離脂肪 酸が末梢の脂肪組織から動員され，これが肝細胞のミ トコンドリアにおいて $\beta$ 酸化され, エネルギー源とな る"1. 完全な絶食下では肝の糖新生は著減し, 肝に脂肪 が沈着することもないが, この際, 少量の炭水化物が 補われると動員された脂肪酸は酸化されず，中性脂肪 に変化して肝細胞に蓄積される ${ }^{1}$.さらに, 絶食状態で は肝細胞のミトコンドリアに形態変化が生じること ${ }^{151}$ から, ミトコンドリア機能の障害により脂肪酸の $\beta$ 酸 化が抑制される可能性も考えられる。一方，合成され た中性脂肪は蛋白質と結合し VLDL として肝から血 中へ分泌されるが, その際にレシチンやアポ蛋白 B が 必要である ${ }^{1,14,16)}$. 低栄養状態では蛋白質の欠乏, とり わけメチオニンの欠乏によりレシチンの生成が低下す $3^{16)}$ ともに, アポ蛋白 B の産生も低下すると考えら れ, 中性脂肪の分泌が抑制されると推測される. 事実, 著しい脂肪肝を伴う低栄養状態では血清中性脂肪, VLDL レベルが低下しており，蛋白質の摂取によりこ れらが著明に上昇することが知られている ${ }^{14}$.

\section{2. 栄養障害と NASH}

$\mathrm{NASH}$ と肥満との密接な関係は古くから指摘され ている ${ }^{12)}$. 多数の剖検例を検討したWanless ら ${ }^{17}$ は, 著しい肥満者の $18.5 \%$ ，やせた患者の $2.7 \%$ NASH 
の合併を認めており，肥満との関係が深かったとして いるが，肥満者のなかではとくに空腸・回腸吻合術例 に本症がみられやすいことに注目している。欧米では 病的肥満者の減量法として本手術が行われた時期があ り, Peters ら ${ }^{18)}$ は1975年に術後に肝不全死した 4 例の 肝組織像がアルコール性肝障害の組織像に類似してい ることを指摘している。その後,この病変は NASH の 概念に包括されるようになり ${ }^{91}$ ，他の減量手術を受け た肥満患者や手術以外の手段で急速に減量した肥満者 にも同様の病変が認められたことから，極端な隇量自 体がNASHの原因となる可能性が考えられてい $3^{10)}$.一方，低栄養に起因するNASH を記載した論文 はこれまでほとんどなく, protein-calorie malnutrition や飢餓状態では脂肪肝はみられても NASH とく に重症例の報告はみられない. AN では18〜 45\%に肝 障害がみられることが報告されている年名が, NASHや 肝不全をきたした例の報告は稀である。ただし，本症 の肝障害は栄養障害の改善とともに通常柽快し, 組織 学的検索がなされることが稀なため, NASH の病変が 実際に少ないのかどうかは明らかでない.ともあれ， 野添ら ${ }^{20)}$ が指摘しているように, AN においても徐々 に体重減少をみる場合には肝機能障害は著しくなく, 短期間の体重減少が高度の肝機能障害の原因になるよ うである。

ところで, 肝細胞への脂肪沈着は過栄養性脂肪肝と NASH に共通の現象であるのに，何が NASH の病態 をこのように重篤化させるのか．この点を考えるヒン トとなるのは, Wanless ら ${ }^{17)}$, Andersen ら ${ }^{211}$ の観察で ある.多数の剖検例を検討したWanless ら ${ }^{17}$ は肥満者 のうち, 死亡直前に体重減少を認めた例に NASH の 頻度が高く,この異化六進状態は空腸・回腸吻合術後 の低栄養に関係があるとしている，また，Andersen $ら^{211}$ は脂肪肝を伴う病的な肥満者を厳しい低力ロリー 食条件下に置いて急激な減量を達成すると, 脂肪肝は 改善するが，その一方で門脈域の炎症や線維化の危険 性が増すことを認めており, 体重減少量と肝脂肪減少 量が門脈線維化の程度と相関することから, 肝内外の 貯蔵脂肪の急速な動員が肝毒性因子の放出につながる 可能性があるとしている，すなわち，NASH は肥満例 に多いことは事実であるが，ANのような低栄鏊状態 にもみられる病変であり, 重篤な炎症や線維化は急激 な体重減少に関係しているように思わ机る。

\section{3. steatohepatitis の原因}

栄養障害者と低栄養条件下の肥満者の共通項は末梢 の脂肪組織からの遊離脂肪酸の動員である. Andersen $ら^{21)}$ は貯蔵脂肪の急速な動員が肝毒性因子の放出につ ながるとしたが, アルコール多飲, 肥満者における急 激な減量, 低栄養という異なった条件下において, 重 症型の steatohepatitis という共通の組織変化が生じ る事実は, これらに共通した肝毒性因子の存在を示唆 するものといえる. 少なくとも, これらの肝障害の発 現には共通の pathway が存在すると言っても過言で はないであろう。では,これらの病態に共通するもの は何であろうか。

これらの患者が共通した遺伝的素因をもっており， 上述した種々の条件下に置かれると steatohepatitis を起こすのではないかという推測は興味深いがこうし た観点からの研究はいまだ行われていない”.また, 糖 尿病や肥満時にはインスリン感受性低下のために steatohepatitis が生じ, 高インスリン血症と中毒性の 遊離脂肪酸の蓄積をきたすという仮説吾)があるが, 飢 餓などの栄養障害時に同様の高インスリン血症やイン スリン感受性低下があるとは考えにくい。もちろん， 治療手段として中心静脈栄養を加えた際, グルコース の過剩が高インスリン血症を招き, 脂肪酸の合成増加 や肝臓への取り込みが増加し, 脂肪肝をきたすことは ありうる ${ }^{9.221}$ が，これが steatohepatitis という炎症反 応を導くとは考えにくい.ともあれ，今回の山口らの 報告を含め, 肝障害を伴う低栄養状態に扔ける遊離脂 肪酸やインスリンに関する知見は乏しく, 内分泌・代 謝動態と steatohepatitis との関係については検討の 余地がある.

ところで, アルコール多飲, 空腸・回腸吻合術, 低 栄養に共通する肝毒性因子として注目されるのはグラ ム陰性桿菌に由来するエンドトキシンである.アル コール多飲時に腸管からのエンドトキシン吸収が方進 し, 網内系機能の低下とあいまって, エンドトキシン 血症が生ずることはよく知られている ${ }^{23 \sim 26)}$.さらに, 慢性エタノール投与ラットにエンドトキシンを投与す るとアルコール性肝炎類似の病態を作製し得るこ と 27.28)などから, エンドトキシンは steatohepatitisの 発現にかかわる重要な因子と考えられている。また， 空腸・回腸吻合術施行例の肝障害の発現にも吻合領域 における腸内細菌の増殖に由来するエンドトキシンの 関与が考えられており", metronidazole の投与が肝障 
害を抑制し，その効果が栄養障害の改善とは無関係で あることが報告されている ${ }^{29}$. 低栄養状態における工 ンドトキシン血症についてはいまだ知見がそしく，山 ロらも今回血中エンドトキシンを测定していないが, 寺田ら ${ }^{8}$ は上述した肝不全死例の入院時に血中エンド トキシンレベルの上昇を認めている.実験的には,ラッ 卜をIVH管理下に扔て腸管を空虚にしておくと消 化管粘膜の萎縮とともに血中エンドトキシンの増加が みられる ${ }^{30)}$.さらに, 低栄養状態下では重篤なアルコー ル性肝障害の場合と同様に血中でエンドトキシンを不 活性化する結合蛋白が減少することが予想される。そ の結果, 大量のエンドトキシンがマクロファージに取 り込まれ, TNF- $\alpha$, IL-8などの炎症性サイトカインの 放出を介して steatohepatitis が惹起されるという推 論も可能であろう。ささら, 重篤な肝不全とそれに続 発する DIC, 多臓器不全という致死的な病態推移 ${ }^{8}$ は 重症型アルコール性肝炎の経過 ${ }^{311}$ 類似しており, と もに十分にエンドトキシンの関与が示唆されるもので ある。

\section{4. おわりに}

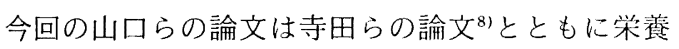
障害性肝障害を再認識させる貴重な報告といえる。今 後, AN 例を中心に, 多数の症例に組織学的検討が加え られ, エンドトキシン, サイトカイン, 代謝・内分泌 動態との関連のもとに, NASH の本態が解明されるこ とが望まれる。栄養障害は重症型アルコール性肝炎の 予後悪化因子としても重要なものであり ${ }^{29)}$,この分野 の成果はアルコール性肝障害の研究にも還元されるで あろう、栄養障害性肝障害を見直すことにより，われ われは肝障害の発現機序に関する新たな視点を得るの ではなかろうか.

\section{文献}

1) Alpers D, Sabesin S, White H: Fatty liver: Biological and clinical aspects. In: Schiff $L$, Schiff E, ed. Diseases of the Liver, 7th ed. Philadelphia: JB Lippincott Company, 1993 : $825-855$

2) 原田直太郎, 今西 宽: 著明な肝機能異常を示し たAnorexia Nervosaの 1 例. 日内会誌 70 : 1462-1463, 1981

3）山形章夫, 広瀬昭一郎, 若梁宣人, 他: 著明な肝機 能異常を呈した神経性食欲不振症の 2 例. 日内会 誌 $78: 563-564,1986$
4）稲本善人，奥野府夫，平野芳明，他：飢餓により著 明な肝障害をきたした 2 症例, 䠦床消化器内科 $6: 729-734,1991$

5）村上伸治, 青木省三, 澤山木ノ芽, 他 : Anorexia Nervosaにみられる重篤な肝障害. 心身医 32 ： $368-373,1992$

6）大川貴志, 藤沢知雄, 藤塚 聡, 他：著明な肝機能 異常を呈した神経因性食欲不振症の 2 例. 日本小 児栄䫞消化器病学会誌 $6: 219-224,1992$

7）坂口守男, 白井俊由, 百溪陽三, 他：テタニーと高 度な肝機能障害を呈した神経性無食欲症の 1 例. 精神医学 35:1081-1087, 1993

8）寺田光宏, 木谷 恒, 増田信二, 他：神経因性食思 不振症の経過中, 著明な肝腫大を呈し, 朋不全にて 死亡した nonalcoholic steatohepatitis 01 例. 肝 臓 $38: 617-621,1997$

9) Ludwig J, Viggiano TR, McGill DB, et al: Nonalcoholic steatohepatitis: Mayo clinic experiences with a hitherto unnamed disease. Mayo Clin Proc 55: 434-438, 1980

10) Ludwig J, McGill DB, Lindor KD: Review : nonalcoholic steatohepatitis. J Gastroenterol Hepatol 12: 398-403, 1997

11) Powell EE, Cooksley WG, Hanson R, et al : The natural history of nonalcoholic steatohepatitis: a follow-up study of forty-two patients for up to 21 years. Hepatology $11: 74-$ 80, 1990

12) Bacon BR, Farahvash MJ, Janney CG, et al : Nonalcoholic steatohepatitis: An expanded clinical entity. Gastroenterology 107: 11031109,1994

13) Sheth SG, Gordon FD, Chopra S: Nonalcoholic steatohepatitis. Ann Intern Med 126: 137 $-145,1997$

14）辻井 正：脂肪肝. 日内誌 $83 ： 446-45(), 1994$

15）松行真門, 吉田一郎, 弓削 健, 他：絶食に上るラ ット肝ミトコンドリアの変化. 肝淢 $28: 264-$ 266, 1987

16）細田四郎, 中條 忍, 絟庭昭彦, 他：栄養性肝障害. 日本臨牀 46 (増刊号) : 398-401, 1988

17) Wanless IR, Lentz JS: Fatty liver hepatitis (steatohepatitis) and obesity: an autopsy study with analysis of risk factors. Hepatology 12 : 1106-1110, 1990

18) Peters R, Gay T, Reynolds TB: Post- 
jejunoileal bypass hepatic disease: Its similarity to alcoholic hepatic disease. Am J Clin Pathol 63:318-331, 1975

19）櫻本美輪子, 末松弘行：神経性過食症と神経性食 欲不振症. 別冊日本臨牀「肝胆道系症侯群肝臟編下 巻」, 日本臨牀社, 東京, 1995, p 345-347

20）野添新一, 増田彰則, 添嶋裕嗣, 他：攝食障害患者 における血清酵素 (とくにGOT, GPT) の異常に ついて. 厚生省特定疾患, 中枢性摂食異常調査研究 班，平成元年度研究報告書 $106-112 ， 1990$

21) Andersen T, Gluud C, Franzmann MB, et al: Hepatic effects of dietary weight loss in morbidly obese subjects. J Hepatol 12: 224-229, 1991

22) Quigley EMM, Marsh MN, Shaffer JL, et al: Hepatobiliary Complications of total parenteral nutrition. Gastroenterology 104 : 286-301, 1993

23) Nolan JP: Endotoxin, reticuloendothelial function, and liver injury. Hepatology $1: 458-$ 465,1981

24) Nolan JP: Intestinal endotoxins as mediators of hepatic injury: an idea whose time has come again. Hepatology 10:887-891, 1989

25) Bode C, Kugler V, Bode JC: Endotoxemia in patients with alcoholic and nonalcoholic cirrhosis and in subjects with no evidence of chronic liver disease following acute alcoholic excess. J Hepatology 4:8-14, 1987

26) Fukui H, Brauner B, Bode JCh, et al : Plasma endotoxin concentrations in patients with alcoholic and non-alcoholic liver disease : reevalua- tion with an improved chromogenic assay. Journal of Hepatology $12: 162-169,1991$

27) Arai M, Nakano S, Okuno F, et al: Endotoxin-induced hypercoagulability: a possible aggravating factor of alcoholic liver disease. Hepatology 9 : 846-851, 1989

28) Fukui $H$, Kitano $H$, Morimura $M$, et al: Metabolic fate of endotoxin and blood tumour necrosis factor levels in rats with acute and chronic alcohol loading. Alcohol Alcoholism 28 (S1A) : 65-70, 1993

29) Drenick E, Fisler J, Johnson D: Hepatic steatosis after intestinal bypass: prevention and reversal by metronidazole, irrespective of protein-calorie malnutrition. Gastroenterology $82: 535,1982$

30）田崎賢一，望月英隆，中川浩二，他：IVH 施行時 にみられる肝障害発生機序に関する実験的研究一 内因性エンドトキシン血症の関与について。外科 と代謝. 栄養 20：297-299，1986

31) Ishii K, Furudera S, Kumashiro R, et al : Clinical and pathological features, and the mechanism of development in severe alcoholic hepatitis, especially in comparison with acute type fulminant hepatitis. Alcohol Alcohol 28 (SIB) ; 97-103, 1993

32) Mendenhall CL, Moritz TE, Roselle GA, et al : Protein energy malnutrition in severe alcoholic hepatitis : diagnosis and response to treatment. The VA Cooperative Study Group \#275. Jpen J Parenter Enteral Nutr 19: 258-265, 1995 